\title{
Edible Giblets and Bone Mineral Characteristics of Two Slow-Growing Chicken Genotypes Reared in an Organic System
}

\section{-Author(s)}

\section{Eleroğlu $\mathrm{H}^{\prime}$ \\ Yıldırım A" \\ Duman M"II \\ Şekeroğlu $A^{I N}$}

Şarkışla Aşık Veysel Vocational School, Cumhuriyet University, Sivas/Turkey e-mail: eleroglu@cumhuriyet.edu.tr

" Department of Animal Science, Faculty of Agriculture, University of Gaziosmanpaşa, Tokat/Turkey

e-mail: arda.yildirim@gop.edu.tr

III Bor Vocational High School, Ömer Halisdemir University, Niğde/Turkey e-mail: mustafa.duman@ohu.edu.tr

iv Department of Animal Production and Technologies, Faculty of Agricultural Sciences and Technologies, Ömer Halisdemir University, Niğde/Turkey

e-mail: ahmet.sekeroglu@ohu.edu.tr

\section{ABSTRACT}

This study was conducted to compare edible giblets weight, tibial bone mineral density (BMD), and bone mineral content (BMC) of two slow-growing broiler genotypes (Hubbard S757; S757 and Hubbard Grey Barred JA; GB-JA) reared with outdoor access, and to determine the relationship between these variables. Day-old chicks (straight-run) of the genotypes $S 757(n=120)$ and GB-JA $(n=120)$ were housed for 98 days. Each genotype was assigned to six pens of 20 birds each. Birds were reared in indoor floor pens and moving shelters with outdoor access (during daylight hours). Absolute body (BW), heart (HW), spleen (SW), liver (LW), gizzard (GW), and abdominal fat pad (AFW) weights of the genotype $\mathrm{S} 757$ and male birds were statistically higher than that of the genotype GB-JA and female birds. Genotype statistically affected relative HW, whereas sex affected relative GW. Although BMD values were not influenced by genotype or sex, S757 birds and males presented statistically higher tibial BMC, lean, lean+BMC, total mass values $(\mathrm{g})$ and area $\left(\mathrm{cm}^{2}\right)$ compared with GB-JA birds and females. BW, HW, SW, LW, GW and AFW were positively correlated with BMC obtained by DXA. In conclusion, the measured traits influenced by genetic strain and sex. The use of the Hubbard $\mathbf{S 7 5 7}$ genotype in organic production systems with outdoor access is recommend.

\section{INTRODUCTION}

Although environmental factors such as management, feeding, movement, toxins, and infectious diseases can play very important roles in the development of skeletal structure, genetic background also has a fundamental influence (Rath et al., 2000). Modern broiler genotypes have been subjected to intensive selection for body weight gain. This selection has resulted in major changes in the anatomy and physiology of broilers, such as increased fat deposition, metabolic diseases, and abnormal skeletal development, including leg disorders, lameness, twisted legs, tibial dyschondroplasia, and crooked toes (Bradshaw et al., 2002; Decuypere et al., 2003; Oviedo-Rondon et al., 2006; Scahaw, 2000).

Conventional intensive production conditions do not allow sufficient exercise and typically present poor hygiene, resulting in leg weakness and skin infections (Bessei, 2006; Talaty et al., 2009). It has been demonstrated that the bones of fast growing meat-type chickens are often abnormally developed, and present high porosity and much lower density than those of slow-growing broilers (Bennett, 2008; Williams et al., 2004). Chickens living freely in their natural habitats did not appear to have such problems (Newberry, 1995), and present much stronger muscle structures (Balog, 1997; Le Van, 2000; Shields, 2004). The genetic selection for growth rate and the feed conversion ratio has altered the relative growth of organs in modern broiler lines when 
compared with heritage lines (Lippens, 2003; Schmidt et al., 2009) and the increasing muscle weight of modern broiler lines is accompanied by a decrease in edible giblets weight (Janiszewska et al, 1998; Plavnik \& Hurwitz, 1982). The changes in the weight of edible giblets occur at different rates (Murawska et al., 2011; Tüzün \& Aktan, 2012).

Because of bone ash (Onyango et al., 2003) and its high correlation with live scans (Schreiweis et al., 2005), excised bones can also be scanned using DXA to assess bone quality. Bone mineral density (BMD, g/ $\mathrm{cm}^{2}$ ) (Kim et al., 2006; Lian et al., 2004; Onyango et al., 2003; Rath et al., 2000; Shim et al., 2012; Watkins and Southern, 1992) and bone mineral content (BMC, $\mathrm{g} / \mathrm{cm}$ ) (Akpe et al., 1987; Almeida et al., 2008; Kim et al., 2006, Onyango et al., 2003) measurements have been used to evaluate the quality and the status of the porous structure of bone matrix. These two parameters are greatly influenced by mineral intake. $B M D$ is a noninvasive method using dual-energy $x$-ray absorptiometry (DXA) that has also been employed to predict osteoporosis in humans (Bolotin, 2007; Koo, 2000). DXA could also be used to measure BMC in broilers and laying hens (Schreiweis et al., 2005; Shim et al., 2012; Talaty et al., 2010).

Comparative research among different slowgrowing broiler strains may be used to establish physiological and morphological adaptations in response to distinct selective pressures. The purpose of this study was to compare the BMD, BMC, and giblet weights of two slow-growing broiler genotypes selected for organic production.

\section{MATERIAL AND METHODS}

Two hundred and forty male and female Hubbard S757 (S757) and Grey Barred JA (GB-JA) were equally divided between strains were used. Although both these strains present slow growth rates to be used in organic production systems, Hubbard $\mathrm{S} 757$ (S757) and Grey Barred JA (GB-JA) were selected to achieve market weight at 84 and 70 days of age respectively. In the study, one-d-old chicks were weighed, identified by wing band, and randomly allocated to two treatments (genotypes: Hubbard S757 or Hubbard Grey Barred JA) with six replicates of 20 birds each. The experiment was approved by the Ethics Committee of the University of Cumhuriyet in Sivas, Turkey (20.06.2011/50).

Twelve portable shelters $(1.5 \times 1.5 \mathrm{~m})$, each housing 20 birds per replicate at a stocking density of 10 birds/ $\mathrm{m}^{2}$ placed in each of the $100-\mathrm{m}^{2}$ grazing areas. The research was carried out according to the principles and implementation of regulation on organic agriculture (OFL, 2010) published by the Republic of Turkey, Ministry of Food, Agriculture and Livestock. During the first 14 days, chicks were housed in the portable shelters, and offered feed and water ad libitum. After this period chicks were allowed to access outdoors and to graze freely. All feed and water were provided between 07:00-19:00 for all chicks during the entire experimental period.

Birds were fed with a three-phase organic diet: a starter diet (197 g crude protein (CP)/kg and $13.00 \mathrm{MJ}$ of metabolizable energy (ME) per $\mathrm{kg}$ of diet) from 0 to 28 days, a grower diet $(201 \mathrm{~g} / \mathrm{kg} \mathrm{CP}$ and $12.72 \mathrm{MJ}$ of ME per $\mathrm{kg}$ of diet) from 29 to 81 days, and a finisher $\operatorname{diet}(180 \mathrm{~g} / \mathrm{kg} \mathrm{CP}$ and $12.91 \mathrm{MJ}$ of ME per $\mathrm{kg}$ of diet) from 82 to 98 days (Table 1).

Only natural day length lighting was provided for chickens from first days to slaughter age. Ceramic heaters, which are sources of far infrared rays and do not emit light, were used for heating.

All birds used in the experiment were managed following the recommendations of Sirri et al. (2011). Birds were fed certified organic feedstuffs, and provided with a cultivated poultry pasture, consisting of equal amounts of Lotus corniculatus and Bromus inermis.

At the end of the 98-day trial period, bone properties were assessed in 24 males and 24 females whose body weights (BW) were close to the pen average (Eleroğlu et al., 2014a). These 48 birds were fasted for $10 \mathrm{~h}$ (with free access to water), weighed, and slaughtered by severing the throat and major blood vessels of the neck in the local processing plant producing organic chicken products (Eleroğlu et al., 2014b). After slaughter, hot carcass weight was determined in a semi-analytic digital scale with 0.001 -g precision, and then the left tibial bone, heart, spleen, liver, gizzard, and abdominal fat pad were removed and weighed to determine absolute weight and relative weight as a percentage of live body weight. Bone mineral content $(B M C)$, bone mineral density (BMD), lean, lean+BMC, total mass and mass area of the left tibial bone were determined using a total-body dual energy X-ray absorptiometry DXA scanner (QDR 4500W Acclaim, Hologic, USA) at the Nuclear Medicine Department of the Medicine Faculty at Cumhuriyet University.

Data were analyzed using the General Linear Model (GLM) procedure. The effects of genotype, sex, and their interactions on the absolute and relative weights of the body (BW), heart (HW), spleen (SW), liver (LW), gizzard (GW), and abdominal fat (AFW), as well as 
Table 1 - Ingredients and calculated nutritional composition of the experimental diets

\begin{tabular}{lccccccc}
\hline Feedstuffs, \% & 0-28 days & $29-81$ days & $82-98$ days & & Nutritional composition $(\mathrm{g} / \mathrm{kg})$ \\
\hline Barley & 3.45 & 4.50 & 4.50 & ME (MJ/kg) & 13.00 & 12.72 & 12.91 \\
Vegetable oil & 4.36 & 5.00 & 5.00 & Dry matter & 899.00 & 903.00 & 901.00 \\
Wheat bran & 5.00 & 5.00 & 5.00 & Crude protein & 197.00 & 201.00 & 180.00 \\
White wheat & 12.40 & 4.00 & 4.00 & Crude ash & 4.70 & 5.90 & 4.80 \\
Rye & 3.00 & 4.00 & 4.00 & Lysine & 10.80 & 10.60 & 8.50 \\
Corn & 40.00 & 20.00 & 20.00 & Met + Cys. & 6.60 & 6.70 & 5.90 \\
Triticale & - & 22.00 & 32.00 & Threonine & 7.30 & 7.20 & 6.20 \\
Oats & 2.10 & 5.00 & - & Calcium & 10.00 & 11.60 & 9.00 \\
Fish meal & 7.30 & 5.00 & - & Phosphorus & 7.70 & 6.00 & 5.90 \\
Soybean meal & 20.00 & 22.00 & 22.00 & Sodium & 1.90 & 1.80 \\
Dicalcium phosphate & 1.10 & 2.10 & 2.10 & Tryptophan & 2.40 & 2.60 \\
Limestone & 0.74 & 0.80 & 0.80 & Linoleic acid & 31.9 & 32.1 \\
Salt & 0.30 & 0.30 & 0.30 & & & 31.50 \\
Vitamin-mineral premix* & 0.25 & 0.30 & 0.30 & & & 31.3 \\
\hline
\end{tabular}

Explanation: * - Each $\mathrm{kg}$ of vitamin-mineral premix contained: vitamin $\mathrm{A}, 4,400,000 \mathrm{IU}$; vitamin $\mathrm{D}_{3}, 1,600,000 \mathrm{IU}$; vitamin $\mathrm{E}, 20,000 \mathrm{mg}$; vitamin $\mathrm{K}_{3}, 1,600 \mathrm{mg}$; vitamin $\mathrm{B}_{1}, 1,200 \mathrm{mg}$; vitamin $B_{2}, 3,200 \mathrm{mg}$; vitamin $B_{3^{\prime}} 20,000 \mathrm{mg}$; vitamin $B_{5^{\prime}} 6,000 \mathrm{mg}$; vitamin $B_{6^{\prime}} 1,600 \mathrm{mg}$; vitamin $\mathrm{B}_{9^{\prime}} 800 \mathrm{mg}$; vitamin $\mathrm{B}_{1^{\prime}} 8 \mathrm{mg}$; biotin, $80 \mathrm{mg}$; antioxidant, $50,000 \mathrm{mg}$; $\mathrm{Cu}, 6,000$ $\mathrm{mg} ; \mathrm{Fe}, 20,000 \mathrm{mg} ; \mathrm{Mn}, 48,000 \mathrm{mg} ; \mathrm{Se}, 80 \mathrm{mg} ; \mathrm{Zn}, 40,000 \mathrm{mg} ; \mathrm{Co}, 80 \mathrm{mg} ; \mathrm{l}, 500 \mathrm{mg}$.

on BMD and BMC were evaluated using multifactor analysis of variance. The percentage data were converted to arcsines prior to analysis. The relationship between bone mineral characteristics and edible giblets were determined using one-tailed Pearson correlation procedure (SPSS Inc. 2010, Release 16.0). Treatment effects were considered significant at $p<0.05$. Data were expressed as mean values with pooled standard errors (standard errors of the mean, SEM).

\section{RESULTS}

The results of the effects of genotype and sex on edible giblets, abdominal fat, and bone characteristics are given in Table 2 and 3, respectively.
Body weight at slaughter (BW) of the two genotypes investigated under the conditions of the present experiment was accurately measured, and was different from each other. Before slaughter, genotype and sex significantly influenced BW $(p<0.01)$. As shown in Table 2, 5757 males were heavier (2847 g) than GB-JA males (2128 g) and 5757 females (2194 g) were heavier than GB-JA females (1634 g). Males of both evaluated strains were heavier than females $(p<0.01)$. There were significant differences between males and females of the same genotypes $(p<0.01)$. S757 males showed higher BW (2847 g) than females (2194 g), whereas the calculated BW of males and females of the GB-JA genotype were $2128 \mathrm{~g}$ and 1634 $g$, respectively.

Table 2 - Absolute and relative weights of edible giblets and abdominal fat of male and female broilers of two different slow-growing genotypes.

\begin{tabular}{|c|c|c|c|c|c|c|c|}
\hline & \multicolumn{2}{|c|}{ GB-JA $^{1}$} & \multicolumn{2}{|c|}{$S 757^{1}$} & \multirow{2}{*}{$\mathrm{SEM}^{2}$} & \multicolumn{2}{|c|}{$p$ value } \\
\hline & Female & Male & Female & Male & & $\mathrm{G}^{3}$ & $S^{4}$ \\
\hline \multicolumn{8}{|l|}{ Absolute weight (g) } \\
\hline Body & 1634 & 2128 & 2194 & 2847 & 65.31 & ** & ** \\
\hline Heart & 7.13 & 9.57 & 8.59 & 11.91 & 0.31 & ** & ** \\
\hline Spleen & 2.07 & 2.40 & 3.17 & 3.74 & 0.13 & ** & * \\
\hline Liver & 24.55 & 31.35 & 31.73 & 38.71 & 0.9 & ** & ** \\
\hline Gizzard & 32.14 & 37.16 & 41.37 & 46.42 & 1.04 & ** & ** \\
\hline Abdominal fat pad & 27.75 & 38.44 & 39.14 & 50.34 & 2.25 & ** & ** \\
\hline \multicolumn{8}{|c|}{ Relative weight (g/100 g body weight) } \\
\hline Heart & 0.44 & 0.45 & 0.39 & 0.42 & 0.008 & ** & NS \\
\hline Spleen & 0.13 & 0.11 & 0.15 & 0.13 & 0.005 & NS & NS \\
\hline Liver & 1.51 & 1.47 & 1.45 & 1.36 & 0.024 & NS & NS \\
\hline Gizzard & 1.97 & 1.75 & 1.90 & 1.63 & 0.042 & NS & ** \\
\hline Abdominal fat pad & 1.70 & 1.79 & 1.78 & 1.78 & 0.087 & NS & NS \\
\hline
\end{tabular}

Explanations: ${ }^{1}$ - GB-JA = Hubbard Grey Barred JA; S757 = Hubbard S757; ${ }^{2}$ - Standard error of the mean, $\mathrm{G}^{3}-$ Genotype; $\mathrm{S}^{4}-$ Sex; ${ }^{*}-\mathrm{p}<0.05 ;{ }^{* *}-\mathrm{p}<0.01 ; \mathrm{NS}-$ Not significant ( $>0.05)$ 
Table 3 - Bone characteristics of male and female broilers of two different slow-growing genotypes

\begin{tabular}{|c|c|c|c|c|c|c|c|}
\hline Genotype (G)1 & Sex (S) & BMC (g) & Lean $(\mathrm{g})$ & Lean+BMC (g) & Total mass (g) & Mass Area $\left(\mathrm{cm}^{2}\right)$ & $\operatorname{BMD}\left(\mathrm{g} / \mathrm{cm}^{2}\right)$ \\
\hline \multirow{2}{*}{ GB-JA } & $\mathrm{F}$ & 2.37 & 55.78 & 58.15 & 57.10 & 9.96 & 0.237 \\
\hline & $M$ & 4.55 & 86.75 & 91.30 & 89.38 & 16.52 & 0.269 \\
\hline \multirow{2}{*}{$\mathrm{S} 757$} & $\mathrm{~F}$ & 3.57 & 81.65 & 85.22 & 84.31 & 14.45 & 0.256 \\
\hline & M & 5.88 & 109.45 & 115.35 & 113.78 & 21.18 & 0.269 \\
\hline $\mathrm{SEM}^{2}$ & & 0.29 & 3.54 & 3.78 & 3.76 & 0.76 & 0.009 \\
\hline \multicolumn{8}{|l|}{ Main effect of } \\
\hline $\mathrm{G}^{3}$ & & $* *$ & ** & ** & ** & ** & NS \\
\hline$S^{4}$ & & ** & ** & ** & ** & ** & NS \\
\hline
\end{tabular}

Explanations: ${ }^{1}$ - GB-JA = Hubbard Grey Barred JA; S757 = Hubbard S757; ${ }^{2}$ - Standard error of the mean; $\mathrm{G}^{3}$ - Genotype; $\mathrm{S}^{4}-$ Sex; ${ }^{*}-\mathrm{p}<0.05 ;{ }^{* *}-\mathrm{p}<0.01, \mathrm{NS}-$ Not significant $(p>0.05)$

Absolute HW, SW, LW, GW and AFW (g) were influenced by genotype, with $\mathrm{S} 757$ birds presenting higher values than GB-JA birds $(p<0.01)$. On the other hand, no differences in HW, SW, LW, GW, and AFW relative to body weight ( $\mathrm{g} / 100 \mathrm{~g}$ body weight) were detected between genotypes, except for HW, which was higher $(\mathrm{p}<0.01)$ in GB-JA $(0.45 \mathrm{~g})$ than in 5757 $(0.41 \mathrm{~g})$ birds.

The absolute HW (11.91 g), SW (3.74 g), LW (38.71 g), GW (46.42 g) and AFW (50.34 g) of 5757 males were higher $(p<0.01)$ than absolute HW $(9.57 \mathrm{~g})$, SW (2.40 g), LW (31.75 g), GW (37.16 g) and AFW (38.44 g) of GB-JA males. Similarly, absolute HW (8.59 g), SW (3.17 g), LW (31.73 g), GW (41.37 g) and AFW (39.14 g) values of $\mathrm{S757}$ females were higher compared with GBJA females, which presented HW (7.13 g), SW (2.07 g), LW (24.55 g), GW (32.14 g) and AFW (27.75 g) ( p<0.01, $p<0.05)$. Neither genotype no sex influenced $(p>0.05)$ relative SW, LW and AFW (g/100 g BW). However, relative HW $(p<0.01)$ was significantly higher in 5757 birds compared with GB-JA birds, independently of sex, and males presented higher relative GW than females $(p<0.01)$, independently of genotype.

A strong effect of genotype and sex was observed on BMC, Lean, Lean+BMC, total mass and mass area $(p<0.01)$. In contrast, genotype and gender effects on BMD were not significant ( $p>0.05)$.

As shown in Table 3, the average BMC (4.72 g), Lean (95.55 g), Lean+BMC (100.28 g), total mass (99.05 g) and mass area $\left(17.82 \mathrm{~cm}^{2}\right)$ values of $\mathrm{S757}$ birds were higher $(p<0.01)$ than the average BMC $(3.46 \mathrm{~g})$, Lean $(71.27 \mathrm{~g})$, Lean+BMC (74.73 g), Total mass $(73.24 \mathrm{~g})$ and Mass area $\left(13.24 \mathrm{~cm}^{2}\right)$ values of GB-JA genotype. On the other hand similar differences was observed between sex, the average BMC (5.51 g), Lean (98.1 $\mathrm{g})$, Lean+BMC (103.33 g), Total mass (101.58 g) and Mass area $\left(18.85 \mathrm{~cm}^{2}\right)$ values of male were higher than the average BMC (2.97 g), Lean (68.72 g), Lean+BMC $(71.69 \mathrm{~g})$, Total mass $(70.71 \mathrm{~g})$ and Mass area (12.21 $\left.\mathrm{cm}^{2}\right)$ values of female $(\mathrm{p}<0.01)$
Table 4 shows the correlations between BW, giblets, abdominal fat, BMC, and BMD values. HW, SW, LW, $\mathrm{GW}$ and AFW were significantly correlated with BW $(r=0.839,0.711,0.826,0.668$ and 0.526 , respectively, $p<0.01$, Table 4). A high correlation of $0.839(p<0.01)$ was especially noted between HW and BW, whereas the correlation of AFW between HW was low ( $r=0.307$; $\mathrm{p}<0.05)$. In addition, BMD, BW, HW, SW, LW and AFW were high significantly correlated with $B M C(r=0.687$, $0.543,0.415,0.396,0.462$ and 0.434 , respectively, $\mathrm{p}<0.01)$ and the correlation GW with BMC was low $(r=0.319 ; p<0.05)$.

\section{DISCUSSION}

The obtained absolute and relative HW, SW, LW, GW and AFW results account indicate that bird growth was isometric, and their genotype, management, and feeding program allowed their normal growth and development under the organic rearing conditions (Plavnik \& Hurwitz, 1982; Lippens, 2003).

The differences in the relative HW detected between the $\mathrm{S} 757$ and GB-JA genotypes may be explained by the selection for different growth rates. The differences in BW led to different relative GW values. Edible internal organ weights relative to hot carcass weight were expected to be higher as the BW at slaughter of broilers reared in organic systems is higher (Eleroglu et al., 2014b). The findings of the current study confirmed this fact.

BMD was not influenced by genotype or sex, on account of this can be said to be similar applied to environmental conditions for both genotype and gender.

Simsek et al. (2009) observed BMC and BMD values of $1.94 ; 0.12$ and $2.01 ; 0.14$ in 42-d-old broilers reared in an enriched and a conventional housing system, respectively. In the present study, BMC values ranged between 2.37 and 5.88, and BMD values between 0.237 and 0.269 in broilers reared in an organic system. The higher BMC and BMD values obtained in 
Table 4 - Correlation coefficients among BW, edible giblets, abdominal fat, BMC and BMD

\begin{tabular}{|c|c|c|c|c|c|c|c|}
\hline Items & BMD & BMC & BW & $\mathrm{HW}$ & SW & LW & GW \\
\hline BMD & 1 & & & & & & \\
\hline $\mathrm{BMC}$ & $0.687^{* *}$ & 1 & & & & & \\
\hline BW & 0.125 & $0.543^{* *}$ & 1 & & & & \\
\hline $\mathrm{HW}$ & 0.065 & $0.415^{* *}$ & $0.839 * *$ & 1 & & & \\
\hline SW & 0.136 & $0.396^{* *}$ & $0.711 * *$ & $0.537 * *$ & 1 & & \\
\hline LW & 0.058 & $0.462 * *$ & $0.826^{* *}$ & $0.767 * *$ & $0.668 * *$ & 1 & \\
\hline GW & 0.059 & $0.319 *$ & $0.668 * *$ & $0.620 * *$ & $0.509 * *$ & $0.679 * *$ & 1 \\
\hline AFW & 0.145 & 0.434 ** & 0.526 ** & $0.307^{*}$ & $0.399 * *$ & $0.484 * *$ & 0.136 \\
\hline
\end{tabular}

Explanations: ${ }^{* *}$ - Correlation is significant at ${ }^{*} p<0.05 ;{ }^{* *}-p<0.01$

the present study may be attributed to age at slaughter (98 days), whereas in Simsek et al. (2009), broilers were slaughtered with 42 days of age. Rath et al. (2000) indicated that BMC and BMD vary according to the age of the skeletal structure, Williams et al. (2004) and Bennett (2008) slow-growing genotypes present better skeletal structure compared fast-growing broilers.

In the present study, a positive correlation between BW and edible giblets and abdominal fat was determined. Genetics and environmental factors, such as feeding, housing, and management, influence BW and the relative growth of internal organs (Ramadan et al., 2014; Tavárez et al., 2016), resulting in changes in the coefficients of correlation between BW and organ relative weights. The correlation coefficients were unexpected and possiblty related with allometric internal organ growth.

The positive correlation between BW and BMC observed in the present study is in agreement with previous studies (Schreiweis et al., 2004; Salas et al., 2012). In addition, this correlation indirectly affected the correlation of BMC with the internal organs. Bone breaking strength, bone ash concentration, and bone weight are positively correlated with BMD and BMC obtained by DXA in chickens (Fleming et al., 1994; Mazzuco and Hester, 2005; Kim et al., 2006, 2008). There is a strong correlation between BMD and BMC $(r=0.81 ; p<0.01)$ in White Leghorns (Hester et al., 2004) as well in male broilers of commercial lines (Talaty et al., 2010). In addition, relatively larger bones present higher BMC correlation with total bone mineral content and are stronger and BMD and BMC values increase with broiler BW (Schreiweis et al., 2004).

The correlation between BMC and tibia ash content is reported as $86 \%$ in commercial broilers (Onyango et al., 2003), and BMC has been described as a better indicator of $\mathrm{Ca}$ and $\mathrm{P}$ nutrition than BMD (Yan et al., 2005). It is concluded that DXA can be used to assess bone mineralization status and bird welfare as a function of their correlation with BMC and BMD.

\section{CONCLUSIONS}

The results of this study showed the importance of genetic and environmental influences on the bone development of broilers. The positive correlation between BMD values and the weight of internal organs should be further studied.

\section{ACKNOWLEDGEMENTS}

This study was supported by the Research Fund of Cumhuriyet University (Project No: ENF-003), which was approved by the local Ethical Committee of Cumhuriyet University for Experimental Animals.

\section{REFERENCES}

Akpe MP, Waibel PE, Larntz K, Metz AL, Noll SL, Walser MM. Phosphorous availability bioassay using bone ash and bone densitometry as response criteria. Poultry Science 1987; 66: 713-720

Almeida Paz ICL, Mendes AA, Balog A, Vulcano LC, Ballarin AW, Almeida ICL, Takahashi SE, Komiyama CM, Silva MC, Cardoso KFG. Study on the bone mineral density of broiler suffering femoral joint degenerative lesions. Brazilian Journal of Poultry Science 2008; 10: 103-108

Balog JM, Bayyari GR, Rath NC, Huff WE, Anthony NB. Effect of intermittent activity on broiler production parameters. Poultry Science 1997; 76: $6-12$

Bennett MB. Post-hatch growth and development of the pectoral and pelvic limbs in the black noddy, Anous minutes. Comparative Biochemistry and Physiology 2008; A150: 159-168

Bessei W. Welfare of broilers: a review. World Poultry Science 2006; J 62: 455-466

Bolotin HH. DXA in vivo BMD methodology: An erroneous and misleading research and clinical gauge of bone mineral status, bone fragility, and bone remodelling. Bone 2007; 41: 138-154

Bradshaw RH, Kirkden RD and Broom DM. A review of the aetiology and pathology of leg weakness in broilers in relation to welfare. Avian And Poultry Biology Reviews. 2002; 13: 45-103

Decuypere E, Bruggeman V, Barbato GF and Buyse J. Growth and reproduction problems associated with selection for increased broiler meat production. Poultry Genetics, Breeding and Technology, CABIpublishing, Wallingford 2003.

Eleroğlu H, Yıldırım A, Işıklı ND, Şekeroğlu A, Duman M. Comparison of meat quality and fatty acid profile in slow-growing chicken genotypes fed diets supplemented with Origanum vulgare or Melissa officinalis 
Eleroğlu E, Yıldırım A,

Duman M, Şekeroğlu A
Edible Giblets and Bone Mineral Characteristics of Two Slow-Growing Chicken Genotypes Reared in an Organic System

Rath, NC, Huff GR, Huff WE, Balog JM. Factors regulating bone maturity and strength in poultry. Poultry Science 2000; 79: 1024-1032

Salas C, Ekmay RD, England J, Cerrate S, Coon CN. Determination of chicken body composition measured by dual energy X-Ray absorptiometry. International Journal of Poultry Science 2012; 11: 462-468

SCAHAW. Scientific Committee on Animal Health and Welfare, The Welfare of Chickens Kept for Meat Production (Broilers). European Commission, Health and Consumer Protection Directorate-General, Brussels, Belgium 2000; SANCO.B.3/AH/R15/2000

Schmidt CJ, Persia ME, Feierstein E, Kingham B, Saylor WW. Comparison of a modern broiler line and a heritage line unselected since the 1950s. Poultry Science 2009; 88: 2610-2619

Schreiweis MA, Orban Jl, Ledur MC, Moddy DE, Hester PY. Effects of ovulatory and egg laying cycle on bone mineral density and content of live White Leghorns as assessed by Dual-Energy X-Ray Absorptiometry. Poultry Science 2004; 83: 1011-1019

Schreiweis MA, Orban JI, Ledur MC, Moody DE, Hester PY. Validation of dual-energy X-ray absorptiometry in live White Leghorns. Poultry Science 2005; 84: 91-99

Shields SJ, Garner JP, Mench JA. Dustbathing by broiler chickens: a comparison of preference for four different substrates. Applied Animal Behaviour Science 2004; 87: 69-82

Shim MY, Karnuah AB, Mitchell AD, Anthony NB, Aggrey SE. The effects of growth rate on leg morphology and tibia breaking strength, mineral density, mineral content, and bone ash in broilers. Poultry Science 2012; 91: 1790-1795

Simsek UG, Dalkilic B, Ciftci M, Cerci IH, Bahsi M. Effects of enriched housing design on broiler performance, welfare, chicken meat composition and serum cholesterol. Acta Veterinaria Brunensis 2009; 78: 67-74

Sirri F, Castellini C, Bianchi M, Petracci M, Meluzzi A, Franchini A. Effect of fast-, medium- and slow-growing strains on meat quality of chickens reared under the organic farming method. Animal 2011; 5: 312-319

SPSS. Statistical Package in Social Sciences for Windows. Statistical Innovations Inc., Chicago, USA 2010

Talaty PN, Katanbaf MN and Hester PY. Life cycle changes in bone mineralization and bone size traits of commercial broilers. Poultry Science 2009; 88: 1070-1077

Talaty PN, Katanbaf MN, Hester PY. Bone mineralization in male commercial broilers and its relationship to gait score. Poultry Science 2010; 89: 342-348

Tavárez MA, de los Santos FS. Impact of genetics and breeding on broiler production performance: a look into the past, present, and future of the industry. Animal Frontiers 2016; 6: 37-41

Tüzün CG, Aktan S. Residual feed consumption in poultry. Süleyman Demirel University Journal of the Faculty of Agriculture 2012; 7: 115-123

Watkins KL, Southern LL. Effect of dietary sodium zeolite A and graded levels of calcium and phosphorous on growth, plasma, and tibia characteristics of chicks. Poultry Science 1992; 71: 1048-1058

Williams B, Waddington DD, Murray $\mathrm{H}$ and Farquharson C. Bone strength during growth: Influence of growth rate on cortical porosity and mineralization. Calcified Tissue International 2004; 74: 236-245

Yan F, Angel R, Ashwell C, Mitchell A, Christman M. Evaluation of the broiler's ability to adapt to an early moderate deficiency of phosphorus and calcium. Poultry Science 2005; 84: 1232-1241 
In the article Edible Giblets and Bone Mineral Characteristics of Two Slow-Growing Chicken Genotypes Reared in an Organic System published in the Revista Brasileira de Ciência Avícolas/Brazilian Journal of Poultry Science, v19 (1):001-006, in page 001 where it was written

\section{-Author(s)}

\section{Eleroğlu $\mathrm{E}^{\prime}$}

Yıldırım A"

Duman M"II

Şekeroğlu $A^{\mathrm{IV}}$

Şarkışla Aşık Veysel Vocational School, Cumhuriyet University, Sivas/ Turkey

e-mail: eleroglu@cumhuriyet.edu.tr

" Department of Animal Science, Faculty of Agriculture, University of Gaziosmanpaşa, Tokat/Turkey e-mail: arda.yildirim@gop.edu.tr

III Bor Vocational High School, Ömer Halisdemir University, Niğde/Turkey e-mail: mustafa.duman@ohu.edu.tr

Iv Department of Animal Production and Technologies, Faculty of Agricultural Sciences and Technologies, Ömer Halisdemir University, Niğde/ Turkey

e-mail: ahmet.sekeroglu@ohu.edu.tr

\section{the correct form is}

\section{-Author(s)}

\section{Eleroğlu $\mathrm{H}^{\prime}$}

Yıldırım A"

Duman M"II

Şekeroğlu $A^{\mathrm{IV}}$

Şarkışla Aşık Veysel Vocational School, Cumhuriyet University, Sivas/ Turkey

e-mail: eleroglu@cumhuriyet.edu.tr

" Department of Animal Science, Faculty of Agriculture, University of Gaziosmanpaşa, Tokat/Turkey e-mail: arda.yildirim@gop.edu.tr

III Bor Vocational High School, Ömer Halisdemir University, Niğde/Turkey e-mail: mustafa.duman@ohu.edu.tr

Iv Department of Animal Production and Technologies, Faculty of Agricultural Sciences and Technologies, Ömer Halisdemir University, Niğde/ Turkey

e-mail: ahmet.sekeroglu@ohu.edu.tr 